\title{
Ellipsis
}

Volume 43

Article 12

2016

\section{The Ripened Lo of Lolita}

Siera Martinez

Follow this and additional works at: https://scholarworks.uno.edu/ellipsis

\section{Recommended Citation}

Martinez, Siera (2016) "The Ripened Lo of Lolita," Ellipsis: Vol. 43 , Article 12.

DOI: https://doi.org/10.46428/ejail.43.12

Available at: https://scholarworks.uno.edu/ellipsis/vol43/iss1/12

This Poetry is brought to you for free and open access by the Department of English and Foreign Languages at ScholarWorks@UNO. It has been accepted for inclusion in Ellipsis by an authorized editor of ScholarWorks@UNO.

For more information, please contact scholarworks@uno.edu. 


\title{
The Ripened Lo of Lolita
}

\author{
Siera Martinez \\ Ryan Chighizola Prize Honorable Mention
}

He had two wives, seven nymphets and a Lolita immeasurable:

Hum painting nails in his trousers and Dolly holding herself still,

Humbert and Dolores banahnah-chewing and on the coffee-table her dead leaf echo,

all but a reminder, non-existing. And the dolorous woman, in her slacks,

hips protruding, chanted $O$ my Carmen, my little Carmen and Hum said we'll dismiss

why Mrs. Hum's bust bulges and Lola chanted $O$ my charmin' our dreadful fights and Hum reassured

I look at you and know as clearly as I know I am to die, that I love you.

So the lovers romanced like lovers but Lolita felt the fat of thighs,

chanting no girl no more, no girl no more, can't light that fire in his loins no more.

But he adored the way she sang. Lolita like a heavenly siphon in his poisonous wound

so she became his Queendom. He was man she was girl-child and he was man

she woman and no law could ruin. And to Lolita he recited

even if your nipples swell and crack, I'll go mad with tenderness.

But still Lo would dress herself in clothes too big. For she hated her Woman,

so she collected her oxfords and sorted them through, old and faded like the energies of her youth,

and she jammed her feet and said they are beautiful, beautiful, beautiful!

And so she chanted and I'll make his knees like reflections of knees in rippling water.

But the small oxfords gave way to mature growth and the laces busted, like the slacks

and Lo who was once a nymphet, screamed his sin, his soul, honey-hued shoulders

the same silky bare back, juvenile breasts and youthful angularity and slender thighs!

... Only she longed for a time-machine. He longed for romancing hazily

and dolorously, or clearly, clearly and throughout their lives. But Lo with her thighs

like sonorous, parallel sound waves, her dead echoes, her hebephilia done and past,

ruined the womanhood lure and chanted something, something those something nights. 